\title{
AKIBAT HUKUM PERJANJIAN PINJAM-MEMINJAM UANG YANG DINYATAKAN BATAL DEMI HUKUM
}

\author{
Ni Made Ayu Pratiwi, I Nyoman Putu Budiartha, Ni Komang Arini Styawati \\ Fakultas Hukum, Universitas Warmadewa, Denpasar - Bali, Indonesia \\ madeayupratiwi19@gmail.com, budiarthaputu59@gmail.com, arinistyawati@gmail.com
}

\begin{abstract}
Abstrak
Perjanjian pinjam meminjam uang merupakan perjanjian melibatkan pihak debitur dan pihak kreditur. Pada jenis perjanjian ini biasanya dapat memunculkan terjadinya yang disebut dengan perjanjian batal demi hukum. Penelitian ini menggunakan metode hukum normatif yang berdasarkan pendekatan perundang-undangan dan konseptual. Sumber data yang digunakan yaitu bahan hukum primer dan sekunder dengan penelitian pustaka. Teknik pengumpulan data dengan mencatat, mengutip, meringkas kemudian melakukan review terhadap dokumen baik berupa peraturan perundang-undangan, literatur, majalah, surat kabar, dan pasal lain yang berkaitan dengan objek penelitian. Bahan hukum tersebut kemudian disajikan secara deskriptif yaitu berupa kata-kata tertulis atau lisan dari informan yang berkaitan dengan masalah yang dibahas sehingga dapat ditarik kesirnpulan. Tujuan penelitian ini untuk mengetahui perjanjian pinjam meminjam uang yang dinyatakan batal demi hukum dan akibat hukum bagi para pihak dari perjanjian yang batal demi hukum. Hasil analisis menemukan bahwa dapat terjadinya perjanjian batal demi hukum pada perjanjian pinjam meminjam uang Perjanjian batal demi hukum dapat terjadi karena syarat obyektif yang diatur dalam undang-undang tidak terpenuhi dan akibat hukum bagi para pihak tidak tertulis dengan jelas di dalam aturan KUH Perdata, dimana dalam peraturan tersebut hanya memuat mengenai perjanjian pinjam meminjam dan syarat sahnya suatu perjanjian tidak membahas mengenai sanksi bagi para pihak apabila terjadi perjanjian batal demi hukum.
\end{abstract}

Kata kunci : Akibat Hukum, Pinjam Meminjam Uang, Batal Demi Hukum

\begin{abstract}
The money lending and borrowing agreement is an agreement involving the debtor and the creditor. In this type of agreement, there is usually what is called a null and void agreement. This research uses a method based on a statutory and conceptual approach. Sources of data used are primary and secondary legal materials with library research. The technique of collecting data is by recording, quoting, summarizing and then reviewing documents in the form of laws and regulations, literature, magazines, newspapers, and other articles related to the object of research. The material is presented descriptively, namely in the form of written or oral words from the informants relating to the issues discussed so that conclusions can be explained. The purpose of this research is to find out the loan and loan agreement which is declared null and void and the legal consequences for the parties of the agreement which are null and void. The results of the analysis found that the occurrence of a null and void agreement in a money loan agreement. A null and void agreement can occur because the objective requirements stipulated in the law are not fulfilled and the legal consequences for the parties are not clearly written in the rules of the Civil Code, where in The regulation only contains the loan and loan agreement and the validity of an agreement does not discuss the sanctions for the parties in the event of a null and void agreement.
\end{abstract}

Keywords: Legal Consequences, Borrowing Money, Canceled by the Law

\section{PENDAHULUAN}

Negara hukum menempatkan kedaulatan tertinggi berada ditangan rakyat. Indonesia sebagai negara hukum secara umum harus berpayungkan kepada konsepsi negara hukum yang berpegang pada demokrasi, perlindungan pada hak asasi manusia (HAM) serta keadilan yang merata dan tidak memimihak pada satu golongan tertentu. Kekuasaan tertinggi diatur dengan hukum yang berlaku. Hal ini sesuai dengan apa yang diatur dalam Pasal 1 ayat (3) UUD 1945 yang menyatakan bahwa semua warga negara lndonesia dijamin kedudukannya sama di mata hukum dan pemerintahan serta wajib menegakan keadilan tanpa ada pengecualian. Lebih lanjut Pasal 280 ayat (1) UUD 1945 yang mengedepankan kepastian hukum dan Pasal 280 ayat (1) UUD 1945 tentang hak atas perlindungan dari ancaman ketakutan. Ketiga pasal ini terkait dengan perjanjian batal demi hukum. 
Hukum kontrak dalam perkembangan bisnis yang berkembang di era globalisasi menjadi suatu kebutuhan transaksi bisnis. Buku III KUH perdata mengatur mengenai ketentuan yang harus dilakukan para pihak yang melakukan perikatan atau perjanjian dalam praktik bisnis, dimana dengan adanya peraturan yang tertulis ini diharapkan dapat menghindari terjadinya konflik yang tak berkesudahan dikemudian hari. Peraturan ini berisi mengenai tata cara perikatan yang baik dan benar. Pada Pasal 1338 KUH Perdata mengatur mengenai asas kebebasan berjanji atau bersepakat. Dalam Buku KUH Perdata diatur dengan sejelas-jelasnya bagaimana perjanjian itu terbentuk dan harus disepakati oleh yang akan melalui proses pinjam meminjam. Tetapi dalam hal berlakunya perjanjian harus memenuhi komitmen yang dibuat di awal yang mana unruk menghindari terjadinya hal-hal yang tidak diinginkan atau konflik antar pihak. Perjanjian yang dibuat harus pasti secara hukum berlaku dengan seadil-adilnya dan dijunjung dengan asas kejujuran.

Guna mencari keadilan dan kepastian hukum dalam penegakan hukum maka pencari keadilan dalam suatu konflik dapat mengajukan kasusnya ke pengadilan dengan selalu menjunjung asas hukum yang berlaku secara arif dan bijaksana (Ali, 2008). Terdapat dua sisi hukum yang harus dijunjung yaitu yang menjadi daya tarik bersama dalam penegakan hukum, yaitu kutub keadilan dan kepastian hukum (Mertokusumo, 1999) sebab hukum ada karena diadakannya perjanjian masyarakat (Atmaja \& Budiartha, 2019).

Kegiatan transaksi pinjam meminjam uang telah dilakukan oleh manusia sejak berlakunya uang sebagai alat pembayaran. Kegiatan ini sebagai salah satu terusan dari sistem barter yang berlaku sebelum uang itu diakui sebagai alat pembayaran yang sah. Dahulu orang melakukan transaksi dengan melakukan pertukaran barang. Kebiasaan ini menimbulkan suatu kebiasaan baru yaitu kegiatan antara pihak kreditor dan pihak debitur (Bahsan, 2015). Antar kedua pihak ini akan membuat suatu perjanjian pinjam meminjam yang didasarkan pada hukum yang berlaku. Unruk kegiatan pinjam meminjam uang ini sendiri dipayungi oleh KUH Perdata. Segala bentuk mulai dari konrrak perjanjian hingga jaminan diatur dalam peraturan ini. Sejumlah uang yang tertuang dalam perjanjian dikenal oleh masyarakat dengan istilah hutang (Subekti, 1995). Dalam meminjamkan dan meminjam uang, setiap pemberi pinjaman yang meminjamkan uang kepada debirur harus menerapkan prinsip kehatihatian dalam memberikan pinjaman.

Bantahan ini tentu saja dibangun oleh dalil-dalil pihak yang merasakan kerugian. Dalam melakukan kesepakatan, seringkali terjadi hal-hal di luar harapan, dimana salah satu pihak seringkali melakukan penyimpangan atau dalam istilah hukum dikenal dengan istilah wanprestasi. Inilah yang menyebabkan dalam kontrak pinjam meminjam uang sebaiknya dilengkapi dengan perjanjian tertulis hitam diatas putih yang disertai dengan menuangkan tanda tangan diatas materai. Ini menjadi suatu keharusan karena apabila nanti ada pihak yang melanggar perjanjian maka kasus ini dapat dibawa ke Pengadilan. Tetapi sebaiknya dalam penyelesaian masalah sengketa hutang ini diselesaikan dengan cara kekeluargaan terlebih dahulu, tetapi apabila rnelalui jalur ini tidak ditemukan titik terang rnaka jalur penyelesaian dengan ke Pengadilan menjadi solusi yang tepat.

Secara teoritis pengajuan tuntutan ke Pengadilan dapat dilakukan dan sah untuk dilakukan. Terbukanya peluang untuk meminta agar perjanjian yang dibuat menjadi batal secara hukum. Perjanjian yang dibatalkan secara hukum tentunya memberi konsekuensi, baik itu debitur maupun kreditur. Dalam hal ini hukum memberikan keadilan bagi kedua belah pihak agar mendapatkan kepastian dan kadilan hukum yang sama tanpa rnemihak satu pihak saja. Hal ini mengingat bahwa hukum iru adil untuk semua orang. Untuk itu maka dalam membuat perjanjian atau kontrak pinjam meminjam uang sangat perlu agar kedua belah pihak benar-benar membaca secara seksarna apa yang disepakati dan konsekuensi yang harus ditanggung di kemudian hari apabila ada pihak yang melanggar perjanjian sebelum para pihak menandatangani perjanjian dan perjanjian berlaku secara hukum.

Salah satu lembaga yang memberikan jasa pinjam meminjam uang adalah Koperasi. Saat ini perkembangan koperasi cukup meningkat tajam dalam kegiatan simpan pinjam kepada masyarakat. Apabila membahas masalah hutang piutang atau pinjam meminjam maja hal ini tentunya bukan masalah baru, karena hampir di setiap lini masyarakat melakukan kegiatan ini. Baik itu koperasi atau lembaga keuangan lainnya akan rnenempatkan suatu perjanjian yang sah sebagai payung hukum yang sah yang apabila nantinya ada pihak yang melanggar perjanjian, maka perjanjian tersebut dapat diselesaikan melalui jalur hukum yang sepatutnya. Tetapi pada dasarnya terdapat perbedaan antara meminjam uang di bank umum dengan di lembaga keuangan koperasi. Perbedaannya dapat dilihat 
dari prosedur peminjaman dan juga tingkat bunga yang dikenakan. Proses peminjaman uang di koperasi biasanya lebih cepat daripada di bank umum. Tetapi apapun itu dan diamanapun itu baik di bank umum ataupun di koperasi sarna-sarna terdapat bentuk kontrak perjanjian yang mengikat dan berpayungkan pada hukum yang berlaku dan sebelum proses peminjaman selesai terdapat persyaratan yang harus dipenuhi oleh pihak yang meminjam.

Contoh kasus adalah yang terjadi di salah satu Koperasi Simpan Pinjam Sri Wahana dimana ketika meminjamkan uang kepada nasabahnya $\mathrm{Y}$ dengan bunga yang disepakati kedua belah pihak, namun kesepakatan dibuat secara lisan (tanpa kesepakatan tertulis). Ikatan yang terjadi antara kedua belah pihak hanya didasarkan pada rasa percaya. Sampai waktu tertentu, temyata peminjam (nasabah Y) tidak mampu mengembalikan pinjaman dengan tarif yang disepakati. Masalah ini sulit untuk diselesaikan karena KSP Sri Wahana tidak memiliki bukti perjanjian tertulis yang dapat mengakibatkan perjanjian pinjam-meminjam menjadi batal demi hukum karena perjanjian ini sejak awal dianggap tidak berlaku.

Pada dasarnya perjanjian harus diakui terlebih dahulu kedudukannya oleh masing-masing pihak yang telah menyepakati perjanjian tersebut. Sehingga para pihak harus menepati dan melaksanakan perjanjian berupa seluruh kewajiban agar pihak tersebut mendapatkan haknya (Amalia, 2018). Kegiatan pinjam-meminjam uang dapat terlaksana dengan baik apabila telah memenuhi isi perjanjian pinjam-meminjam uang mengenai janji-janji dan kewajiban-kewajiban para pihak tanpa ada salah satu pihak yang dirugikan dalam perjanjian pinjam-meminjam uang ini. Dikarenakan adanya ikatan hukum, apabila dalam suatu waktu terjadi suatu perbuatan yang dapat merugikan pihak atau salah satu pihak tidak memenuhi kewajibannya, maka pihak yang satu atau yang lainnya yang merasa di rugikan dapat menuntutnya di pengadilan sesuai isi dari perjanjian yang telah di buat menurut kesepakatan para pihak (Bandem et al., 2020). Apabila perjanjian telah disepakati antara pihak debitur dan kreditur, maka perjanjian tersebut menjadi mengikat dan mempunyai akibat hukum yang berlaku seperti undang-undang bagi para pembuatnya (Pardana et al., 2019).

Berdasarkan penjelasan diatas, maka dapat dirumuskan tujuan dari penelitian ini untuk mengetahui perjanjian pinjam meminjam uang yang dinyatakan batal demi hukum dan akibat hukum bagi para pihak dari perjanjian yang batal demi hukum

\section{METODE PENELITIAN}

Penelitian ini menggunakan metode hukum normatif yang berdasarkan pendekatan perundangundangan dan konseptual menjadi metode yang dipilih dalam penyelesaian masalah dalam penelitian ini. Selanjutnya untuk mendapatkan jawaban atas perrnasalahan yang dikaji maka dikumpulkan bahan hukum, baik itu bahan hukum primer maupun bahan hukum sekunder dengan penelitian pustaka. Teknik penelitian hukum dikumpulkan dengan mencatat, mengutip, meringkas kemudian melakukan review terhadap dokumen baik berupa peraturan perundang-undangan, literatur, majalah, surat kabar, dan pasal lain yang berkaitan dengan objek penelitian. Bahan hukum tersebut kemudian disajikan secara deskriptif yaitu berupa kata-kata tertulis atau lisan dari informan yang berkaitan dengan masalah yang dibahas sehingga dapat ditarik kesimpulan.

\section{HASIL DAN PEMBAHASAN}

\section{Perjanjian Pinjam Meminjam Uang yang dinyatakan Batal Demi Hukum}

Buku III KUH Perdata menjadi payung hukum yang sah yang mengatur mengenai perjanjian, terrnasuk didalamnya adalah mengenai perjanjian pinjam meminjam uang. Landasan lahirnya suaru perikatan atau perjanjian diatur dalam Pasal 1313, 1320 dan 1338. Dalam Pasal 1313 KUH Perdata dinyatakan bahwa suatu perbuatan yang mengikat satu orang atau lebih terhadap orang lain atau lebih dikenal dengan perjanjian.

Dengan dibuatnya kesepakatan antara kreditur dan debitur otomatis terikat secara hukum. Agar perjanjian menjadi sah rnenurut hukum harus memenuhi persyaratan hukum sesuai yang diatur dalam Pasal $1320 \mathrm{KUH}$ perdata yang terdiri atas kesepakatan yang mengikat, kecakapan dalam membuat klausul hukum dalam kesepakatan, mengandung pokok persoalan yang jelas, adanya kausalitas yang tidak terlarang. 
Perjanjian yang sah pada dasarnya akan mengikat kedua belah pihak yang terlibat dalam perjanjian. Hal ini sesuai dengan bunyi Pasal 1320 ayat I KUH Perdata. Pernyataan ini didasarkan pada asurnsi yang menyatakan bahwa kedua belah pihak bebas dalam rnenentukan isi perjanjian, dimana perjanjian yang nantinya akan terbentuk merupakan bentuk kesepakatan dari kedua belah pihak sehingga kedua belah pihak ini dituntut untuk memenuhi komitmen yang disepakati bersama. Perjanjian tersebut akan menjadi sah secara hukum apabila isi kontrak memenuhi apa yang rnenjadi ketenruan paraturan perundang-undanagan yang berlaku. Apabila nantinya salah satu pihak lalai dan melakukan pelanggaran dalam bentuk wanprestasi maka pihak tersebut harus melakukan pertanggungjawaban seperti apa yang telah disepakati di awal ketika penyusunan klausul-klausul isi perjanjian. Lebih lanjut mengenai hal tersebut diatas telah diatur dalam Pasal 1338 KUH Perdata yang rnenyatakan perjanjian dibuat sesuai dengan undnag-undang yang berlaku bagi mereka yang terlibat dalam kesepakatan. Perjanj ian yang telah dibuat tidak dapat ditarik kembali, kecuali dengan kesepatakan di antara kedua belah pihak yang terlibar dalam pembuatan perjanjian tersebut sesuai dengan peraturan perundang-undangan yang berlaku dan dimana perjanjian tersebut harus dijalankan oleh para pihak dengan asa itikad baik.

Asas kebebasan berjanji diatur dengan jelas dalam Pasal 1338 KUH Perdata. Sesuai dengan yang tertuang dalam Buku III KUH Perdata maka dijelaskan bahwa semua pihak yang terlibat dalam perjanjian bebas menentukan isi perjanjian tetapi tidak dibenarkan untuk membuat klausul tidak sesuai aturan yang ada. Mengenai hal-hal yang disepakati harus sesuai dengan mekanisme dan prosedural yang ada. Dalam hal ini perjanjian yang dibuat harus mampu mengikat para pihak dengan mengedapankan asas kejujuran, keadilan dan kepastian hukum.

Perjanjian pinjam meminjam adalah pedoman dalam melakukan perjanjian kredit, seperti yang diseutkan dalam Pasal 1754 KUH Perdata yang menyebutkan dalam suatu perjanjian terdapat pihak yang memberikan jaminan kepada pihak lain dimana yang memberikan pinjaman, dimana nantinya ketika ada pihak yang melanggar perjanjian maka sejumlah barang tertentu yang telah dijadikan jaminan dapat diambil oleh pemberi pinjaman. Barang yang dijadikan jaminan biasanya merniliki nilai sesuai dengan jumlah uang yang dipinjamkan.

Dalam perjanjian pinjam meminjam uang dikenal dengan berbagai nama diantaranya yang paling dikenal masyarakat luas adalah perjanjian kredit (Sutamo, 2003). Pinjam meminjam uang di tengah perkembangan era global seperti sekarang ini telah menjadi suatu kebutuhan bagi masyarakat. Kegiatan pinjam meminjam ini digunakan untuk kegiatan transaksi baik itu untuk kegiatan bisnis maupun nonbisnis. Untuk kegiatan bisnis biasanya digunakan sebagai modal untuk mengembangkan bisnis, sedangkan untuk kegiatan non bisnis biasanya digunakan untuk mernenuhi kebutuhan seharihari. Baik untuk kegiatan bisnis maupun non bisnis, pinjam merninjam uang dapat dilakukan asalkan rnemenuhi persyaratan dan tetap berdasarkan pada perjanjian yang berlaku secara hukum. Selain itu dalam kegiatan pinjam merninjam uang juga harus terdapat klausul yang mengatur tentang jaminan yang harus dijaminkan oleh pihak perninjam agar ada kepastian dan rasa nyaman pengembalian bagi pihak yang rneminjamkan uang.

Kesepakatan dalam perjanjian pinjam meminjam uang merupakan perwujudan dari kehendak antara para pihak yang dikehendaki untuk dilaksanakan. Keadaan yang tidak pasti dengan kemungkinan ketidaksesuaian isi perjanjian dengan pelaksanaan dapat rnenimbulkan rasa keraguan masyarakat terhadap suaru jasa lembaga keuangan baik bank ataupun lembaga non bank, maka dari itu dalam membuat perjanjian harus menyesuaikan tidak kerugian antar pihak bersangkutan. Selain iru unruk menghindari hal kemungkinan terjadinya wanprestasi terhadap perjanjian yang dibuat semula oleh pihak debitur kepada kreditur, maka lembaga keuangan bank dan non bank harus bisa memberikan perlindungan terhadap jaminan. Dengan adanya ha! tersebut maka diperlukan ketenruan hukum yang berlaku atas kemungkinan terjadinya wanprestasi dalam perjanjian serta resiko akan 
kerusakan terhadap jaminan, dimana dapat menimbulkan kerugian bagi pihak debitur maupun kreditor.

\section{Akibat Hukum Bagi Para Pihak Dari Perjanjian Yang Batal Demi Hukum}

Pasal 1320 KUH Perdata mengatur mengenai persyaratan yang wajib dipenuhi oleh para pihak dalam meakukan perjanjian pinjam meminjam uang. Para pihak akan membuat perjanjian dengan mengedepankan asas keadilan, kejujuran dan kepastian hukum yang mengikat di dalamnya. Kondisi ini akan mencakup baik itu objek ataupun subjek hukum seperti yang tertuang dengan jelas dalam Pasal $1320 \mathrm{KUH}$ Perdata. Pada dasarnya lahirnya suatu perikatan atau perjanjian itu telah diatur dalam peraturan perundang-undangan. Jadi suatu perjanjian tidak lahir begitu saja, tetapi didasari pada paying hukum yang lebih tinggi, meskipun isi perjanjian yang dapat susun damn kemudian disepakati. Adapun syarat sahnya suatu perjanjian diatur dalam Pasal 1320 KUH Perdata terdiri atas empat syarat sah yaitu:

I) Kesepakatan mereka mengikatkan diri

2) Kecakapan untuk membuat suatu perjanjian

3) Suatu hal tertentu

4) Suatu sebab yang halal

Syarat pertama dan kedua dari empat persyaratan yang ada merupakan syarat yang bersifat subjektif. Dimana syarat ini berlaku bagi para pihak yang melakukan perjanjian atau dengan kata lain ketentuannya mengatur para pihak yang terlibat dalam perjanjian. Artinya apabila syarat ini tidak terpenuhi maka perjanjian tidak akan terbenruk dan perjanjian yang ada menjadi tidak sah secara hukum yang berlaku atau dengan kara lain perjanjian yang ada tidak dapat dipertanggungjawabkan secara hukum sehingga nantinya apabi la terdapat pelanggaran pada perjanjian yang disepakati, maka pihak pembuat perjanjian tidak dapat menyelesaikan kasus ini ke Pengadilan. Syarat ketiga dan keempat merupakan syarat objektif, dimana apabila salah satunya tidak terpenuhi maka akan berdampak pada keadaan dimana perjanjian yang dibuat dianggap tidak pemah ada atau batal demi hukum.

Berdasarkan uraian tersebut diatas maka dapat dijelaskan bahwa Buku ill KUH Perdata tentang Perikatan, hanya mengatur tentang bagaimana suatu perjanjian itu terbentuk, kebebasan para phak untuk membuat isi perjanjian tetapi tetap harus didasari atas peraturan hukum yang berlaku dan mengatur juga mengenai syarat sahnya suatu perjanjian. Dalam Buku Ill KUH Perdata dijelaskan mengenai perjanjian yang batal demi hukum. Perjanjian batal demi hukum terjadi karena tidak dipenuhinya syarat ketiga dan keempat yang ada dalam Pasal 1320 KUH Perdata. Tetapi tidak diatur lebihjelas dan detail mengenai akibat hukum yang ada bagi para pihak yang nantinya melakukan perjanjian batal demi hukum. Pada dasarnya perjanjian yang batal demi hukum sama artinya dengan tidak adanya perjanjian yang dibentuk dari awal atau dengan kata lain tidak ada kesepakatan yang terbentuk dari awal. Untuk itu maka dalam membuat suatu perjanjian maka antara para pihak harus dengan jelas menuangkan klausul-klausul hukum yang jelas, terlebih dalam perjanjian pinjam meminjam uang yang rentan menyebabkan terjadinya konflik akibat wanprestasi diantara salah saru pihak atau para pihak yang terlibat dalam perjanjian tersebut.

\section{SIMPULAN DAN SARAN}

\section{Simpulan}

Hasil analisis menemukanjawaban atas permasalahan maka kesimpulannya adalah:

a. Perjanjian pinjam meminjam uang yang dinyatakan batal demi hukum atau tidak memenuhi persyaratan objektif sebagaimana dimaksud dalam Pasal 1320 ayat 4 dan 3 KUHP, yaitu mengenai hal tertenru dan sebab atau sebab yang sah. Dalam perjanjian pinjam meminjam uang tertuang dengan jelas mengenai hak dan kewajiban yang harus disepakati oleh para pihak yang membuat perjanjian. Untuk itu maka bagi para pihak yang terlibat dalam perjanjian yang telah disepakati harus berhati-hati memahami klausul-klasusal hukum yang berlaku di dalamnya unruk menghindari terjadinya perjanjian yang batal hukum.

b. Sesuai dengan Buku III KUH Perdata tentang Perikatan yang didalamnya menjelaskan menganai apa itu perjanjian dan syarat sahnya suatu perjanjian tidak mengatur dengan pasti mengenai akibat 
hukum yang timbul akibat dari perjanjian yang batal demi hukum. Ini karena perjanjian batal demi hukum merupakan perjanjian sebenarnya tidak ada dari awal. Hal ini mengakibatkan tidak ada konsekuensi hukum yang diterima pihak-pihak yang terlibat.

\section{Saran}

Berdasarkan uraian kesimpulan didapat saran sebagai berikut:

a. Dalam perjanjian pinjam meminjam uang harus dibuat secara tertulis dan ditandatangani oleh para pihak di atas materai yang mengikatkan diri pada perjanjian yang dibuat sehingga ada kepastian hukum. Sehingga jika di kemudian hari salah satu pihak yang melakukan wanprestasi maka akta kesepakatan dapat dengan mudah digunakan sebagai alat bukti tertulis di persidangan, dan pihak yang melakukan wanprestasi tidak dapat menyangkalnya.

b. Masyarakat harus lebih berhati-hati dalam membuat perjanjian pinjam meminjam untuk menghindari hal-hal yang tidak diinginkan. Masyarakat diharapkan dapat memenuhi komitmen sesuai dengan apa yang telah disepakati dalam kesepakatan yang telah dibuat. Hal ini karena perjanjian batal demi hukum akan merugikan pihak lain dimana dengan putusan batal demi hukum maka perjanjian tersebut dianggap tidak pemah lahir.

\section{DAFTAR PUSTAKA}

Ali, A. (2008). Menguak Tabir Hukum. Ghalia Indonesia.

Amalia, I. Q. A. (2018). Akibat Hukum Pembatalan Perjanjian dalam Putusan Nomor 1572 K/Pdt/2015 Berdasarkan Pasal 1320 dan 1338 Kuh Perdata. Jurnal Hukum Bisnis Bonum Commune, 1(1), 61-72.

Atmaja, I. D. G., \& Budiartha, 1 N. P. (2019). Sistematika Filsafat Hukum. Setara Pers.

Bahsan, M. (2015). Hukum Jaminan dan Jaminan Kredit Perbankan Indonesia,. PT. Rajagrafindo Persada.

Bandem, I. W., Wisadnya, I. W., \& Mordan, T. (2020). Akibat Hukum Perbuatan Wanprestasi dalam Perjanjian Hutang-Piutang. Jurnal Raad Kertha, 3(1), 1-19.

Mertokusumo, S. (1999). Mengenal Hukum Suatu Pengantar. Liberty.

Pardana, I. N. A., Sihabudin, \& Puspitawati, D. (2019). Implikasi Hukum Penggunaan Data Pribadi Pihak Ketiga terhadap Keabsahan Perjanjian Pinjam-Meminjam Uang Berbasis Teknologi Informasi. Jurnal Ilmiah Pendidikan Pancasila Dan Kewarganegaraan, 4(2), 341-351.

Prabancani, P. A., Arini, D. G. D., \& Astiti, I. G. K. S. (2019). Penyelesaian Wanprestasi dalam Perjanjian Pinjam Meminjam Uang. Jurnal Analogi Hukum, 1(1), 67-70.

Subekti, R. (1995). Aneka Perjanjian. PT. Citra Aditya Bakti.

Sutamo. (2003). Aspek-Aspek Hukum Perkreditan pada Bank. Alfabeta. 